\title{
Surveilens Penyakit Jantung dan Pembuluh Darah di Dinas Kesehatan Provinsi Riau
}

\section{Surveillance of Cardiovascular Disease in Riau Provincial Health Office}

\author{
Mitra* Tin Gustina** Said Mardani, Matwimiyadi, Agus Alamsyah, Muhammadiyah***
}

\author{
*Staf Pengajar STIKes Hang Tuah Pekanbaru \\ **Dinas Kesehatan Propinsi Riau \\ ****Mahasiswa STIKes Hang Tuah Pekanbaru
}

\begin{abstract}
Abstrak
Indonesia sedang mengalami transisi epidemiologi dibuktikan dengan terjadinya peningkatan angka kematian akibat penyakit non infeksi. Salah satu penyakit non infeksi yang saat ini cenderung menunjukkan peningkatan angka kesakitan yang cukup tinggi adalah Penyakit Jantung dan Pembuluh Darah (PJPD). Langkah awal untuk pengendalian dan pencegahan adalah melaksanakan Program Surveilens PJPD melalui deteksi dini. Surveilens aktif di lakukan di Kabupaten Kampar. Hasil Surveilans PPJPD dari faktor risiko adalah obesitas umum 11,2\%, obesitas sentral $41,4 \%$, hiperkolesterol 65,4\%, Diabetes Melitus 5,6\%, dan kelainan jantung 46,2\%. Prevalensi faktor risiko dan gaya hidup adalah kebiasaan merokok 24,3\%, kebiasaan mengkonsumsi alkohol 11,9\%, kebiasaan mengkonsumsi asin 41,2\%, kebiasaan mengkonsumsi lemak tinggi 72,5\%, kurang mengkonsumsi sayur dan buah 53,3\%, kurang aktivitas 59,3\%, dan stress tinggi 35\%. Untuk itu perlu dilakukan survei deteksi dini secara berkala dan berkesinambungan, mengintensifkan penyuluhan kesehatan dan melibatkan peran serta aktif masyarakat.
\end{abstract}

Kata Kunci : Surveilans, Penyakit Jantung dan Pembuluh Darah

\begin{abstract}
Abstrac
Indonesia is experiencing an epidemiological transition that evidenced by the increase of mortality from non-infectious diseases. One of non-infectious diseases that currently trend to show increased morbidity rate is Cardiovascular Disease. The first step for the control and prevention is to carry out surveillance program through early detection. Active surveillance was conducted in Kampar district. The Results risk factors are as follows: $11.2 \%$ obesity, $41.4 \%$ central obesity, $65.4 \%$ hypercholesterolemia, 5.6\% diabetes mellitus and 46.2\% cardiac abnormalities. Risk factors and lifestyle habits are as follows: $24.3 \%$ smoking, $11.9 \%$ alcohol consumption habits, $41.2 \%$ consumption of salty foods, $72.5 \%$ high fat consumption, $53.3 \%$ less to consume vegetables and fruits, 59.3\% less activity and 35\% high stress. It is necessary for early detection of periodic surveys and continuous, intensified health education and involve the active participation of the community.
\end{abstract}

Key Word : Surveillance, Cardiovascular Disease

Alamat Korespondensi : Mitra, STIKes Hang Tuah Pekanbaru Jln Mustafa Sari No 5 Tangkerang Selatan Pekanbaru HP : 08126731772 email : mitra_harau@yahoo.co.id 


\section{Pendahuluan}

Saat ini, Indonesia sedang mengalami transisi epidemiologi yaitu terjadinya pergeseran pola penyakit dari awalnya lebih didominasi oleh penyakit infeksi bergeser ke pola penyakit non infeksi (penyakit kronis, degeneratif dan kecelakaan). Adanya transisi epidemiologi ini salah satunya dibuktikan dengan terjadinya peningkatan angka kematian akibat penyakit non infeksi dari $41,7 \%$ pada tahun 1995 menjadi 59,5\% pada tahun 2007 (Riskesdas, 2007). Mengingat pentingnya pencegahan dan penanggulangan penyakit non infeksi ini, maka diadakan pertemuan Regional Meeting on Health and Development Challenges of Non-Communicable Disease yang dihadiri oleh 11 negara anggota South East Asia Regional Organization (SEARO). Pertemuan tersebut merekomendasikan bahwa pencegahan dan pengendalian penyakit non infeksi menjadi prioritas dalam perencanaan pengembangan dan kebijakan kesehatan di tiap negara anggota SEARO (Depkes, 2009).

Salah satu penyakit non infeksi yang saat ini cenderung menunjukkan peningkatan angka kesakitan yang cukup tinggi adalah Penyakit Jantung dan Pembuluh Darah (PJPD). PJPD merupakan penyebab utama kematian dan ketidakmampuan fisik yang diderita oleh masyarakat Indonesia dan dunia saat ini (Depkes, 2007). Hasil Riskesdas tahun 2007 memperlihatkan bahwa prevalensi beberapa penyakit PJPD di Indonesia sangat tinggi yaitu hipertensi sebesar $31,7 \%$, penyakit jantung $7,2 \%$, dan stroke 8,3 per 1000 penduduk.

Provinsi Riau juga tak luput dari permasalahan PJPD ini. Prevalensi beberapa penyakit PJPD di Provinsi Riau relatif tinggi bahkan melebihi prevalensi nasional. Menurut hasil Riskesdas tahun 2007, prevalensi stroke di Provinsi Riau sebesar 0,5 per 1000 penduduk, prevalensi penyakit jantung sebesar $7,7 \%$. Angka tersebut berada diatas prevalensi nasional yaitu $7,2 \%$. Demikian pula halnya dengan prevalensi hipertensi $(33,9 \%)$ juga berada diatas prevalensi nasional (31,7\%). Berdasarkan data tersebut terlihat bahwa PJPD merupakan masalah kesehatan di Provinsi Riau yang perlu penanganan serius.

Untuk mengantisipasi terjadinya peningkatan morbiditas dan mortalitas akibat PJPD, maka perlu dilakukan upayaupaya promotif dan preventif. Sebagai langkah awal adalah melaksanakan Program Surveilens Penyakit Tidak Menular (PTM) PJPD melalui deteksi dini PJPD di Provinsi Riau. Surveilens dan deteksi dini PJPD ini penting dilakukan guna memperoleh gambaran nyata situasi PJPD di Provinsi Riau beserta faktor risikonya sebagai landasan dalam penyusunan strategi dan kebijakan yang tepat guna, berdaya guna dan berbasis bukti (evidence base) dalam pencegahan dan pengendalian PJPD di Provinsi Riau.

Surveilens PTM khususnya PJPD merupakan salah satu program baru yang berada dalam ruang lingkup Program Surveilens Dinas Kesehatan Provinsi Riau. Surveilens PTM PJPD ini baru mulai dilaksanakan pada tahun 2010 dengan melakukan survei deteksi dini faktor risiko PJPD pada 8 kabupaten/kota $(66,6 \%$ dari total seluruh kabupaten/kota) yang berada di wilayah Provinsi Riau yaitu Kabupaten Kampar, Rokan Hulu, Rokan Hilir, Indragiri Hulu, Indragiri Hilir, Bengkalis, Siak, dan Kota Dumai. Terdapat 4 kabupaten/kota yang masih belum dilakukan survei deteksi dini faktor risiko PJPD pada tahun 2010 yaitu Kabupaten Pelalawan, Kuantan Singingi, Kepulauan Meranti, dan Kota Pekanbaru.

Tujuan dari pelaksanaan surveilens PJPD di Dinas Kesehatan Propinsi Riau adalah untuk mengetahui persentase PJPD dan persentase faktor risiko PJPD di Provinsi Riau khususnya pada masyarakat di tempat deteksi dini dilaksanakan. 


\section{Metode}

Kegiatan surveilens PTM PJPD yang telah dilaksanakan adalah survei deteksi dini PJPD di Kabupaten Kampar. Survei ini merupakan tahap awal dari 12 kabupaten/kota yang telah direncanakan oleh Dinas Kesehatan Kota Pekanbaru selama tahun 2011. Survei deteksi dini ini dilakukan secara aktif dengan melibatkan berbagai elemen pemerintah, mahasiswa, dan masyarakat. Elemen pemerintahan yang terlibat pada kegiatan survei ini adalah Dinas Kesehatan Provinsi Riau (Seksi Surveilens dan Kesehatan Matra), Dinas Kesehatan Kampar, dan UPT Puskesmas Tambang sebagai lokasi survei dilaksanakan. Elemen mahasiswa yang terlibat adalah mahasiswa Stikes Hang Tuah Pekanbaru yang sedang melaksanakan kegiatan Praktikum Kesehatan Masyarakat (PKM) di Dinas Kesehatan Provinsi Riau. Elemen masyarakat yang terlibat langsung pada kegiatan ini adalah kader-kader kesehatan Posyandu Usila di Desa Kuapan dimana survei dilaksanakan.
Kegiatan Pelaksanaan Deteksi Dini PJPD ini menggunakan metode wawancara, observasi dan pengukuran, selain itu juga kegiatan ini menggunakan alat seperti Cardio check, koesioner, tensi meter, timbangan berat badan, pengukur tinggi badan, EKG, dan Micro toise.

Kegiatan Pelaksanaan Deteksi Dini menggunakan sampel sebanyak 406 orang, dari 406 orang ini dilakukan wawancara dan pengukuran tinggi badan, berat badan, berat badan, lingkar perut dan tekanan darah, kemudian dari 406 orang ini dipilih 103 orang yang memiliki atau mendekati faktor risiko PJPD untuk diperiksa kimia darahnya, lalu dari 103 orang, dipilih 13 orang yang memiliki faktor risiko PJPD untuk dilakukan pemeriksaan kelainan jantung dengan menggunakan alat EKG.

\section{Hasil}

Kegiatan surveilens PTM PJPD adalah kegiatan survei deteksi dini faktor risiko PJPD di Kabupaten Kampar. Beberapa permasalahan yang ditemui berdasarkan hasil kegiatan survei ini adalah

Gambar 1

Distribusi Persentase Hasil Survei Deteksi Dini PTM (PJPD) Berdasarkan Faktor Risiko di Desa Kuapan Kecamatan Tambang Kabupaten Kampar Tahun 2011

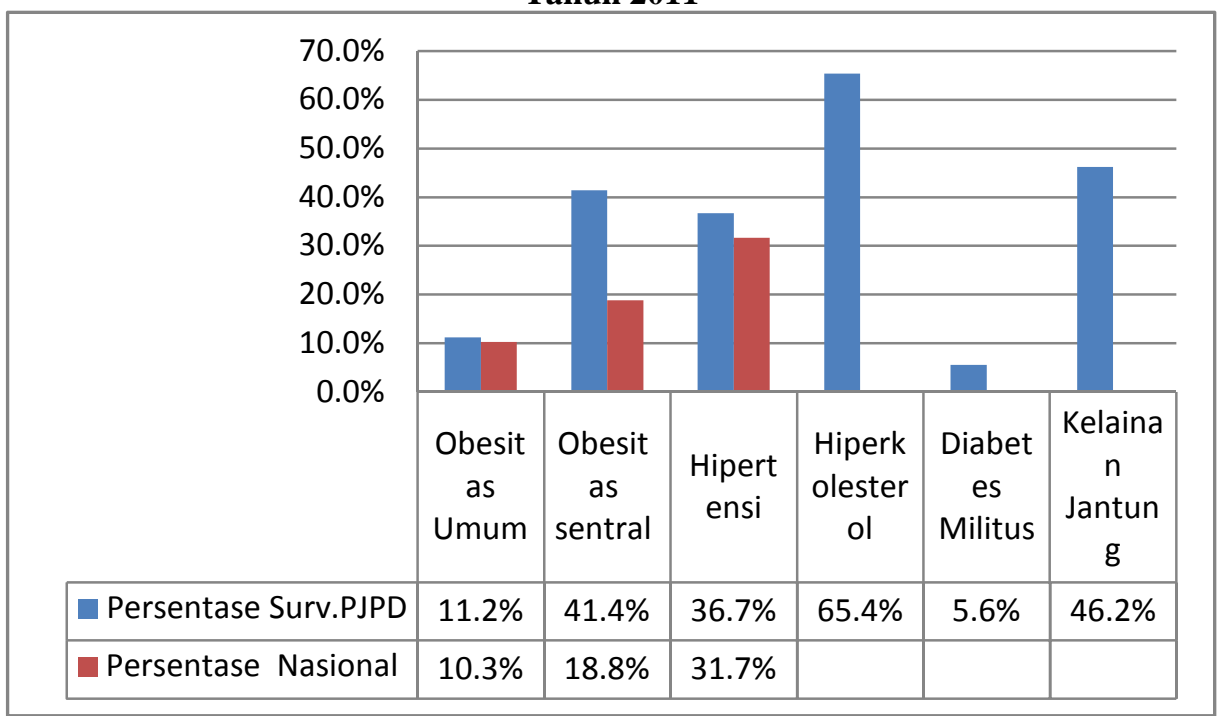

Pada gambar 1 dapat dilihat bahwa Persentase Hasil Survei Deteksi Dini Penyakit Tidak Menular (PJPD) Berdasarkan Faktor Risiko yaitu obesitas umum, obesitas sentral, hipertensi, hiperkolesterol, Diabetes Melitus dan Kelainan Jantung berada di atas Persentase Nasional. 
Gambar 2

Distribusi Persentase Hasil Survei Deteksi Dini PTM (PJPD)

Berdasarkan Faktor Risiko Perilaku dan Gaya Hidup di Desa Kuapan Kecamatan Tambang Kabupaten Kampar Tahun 2011

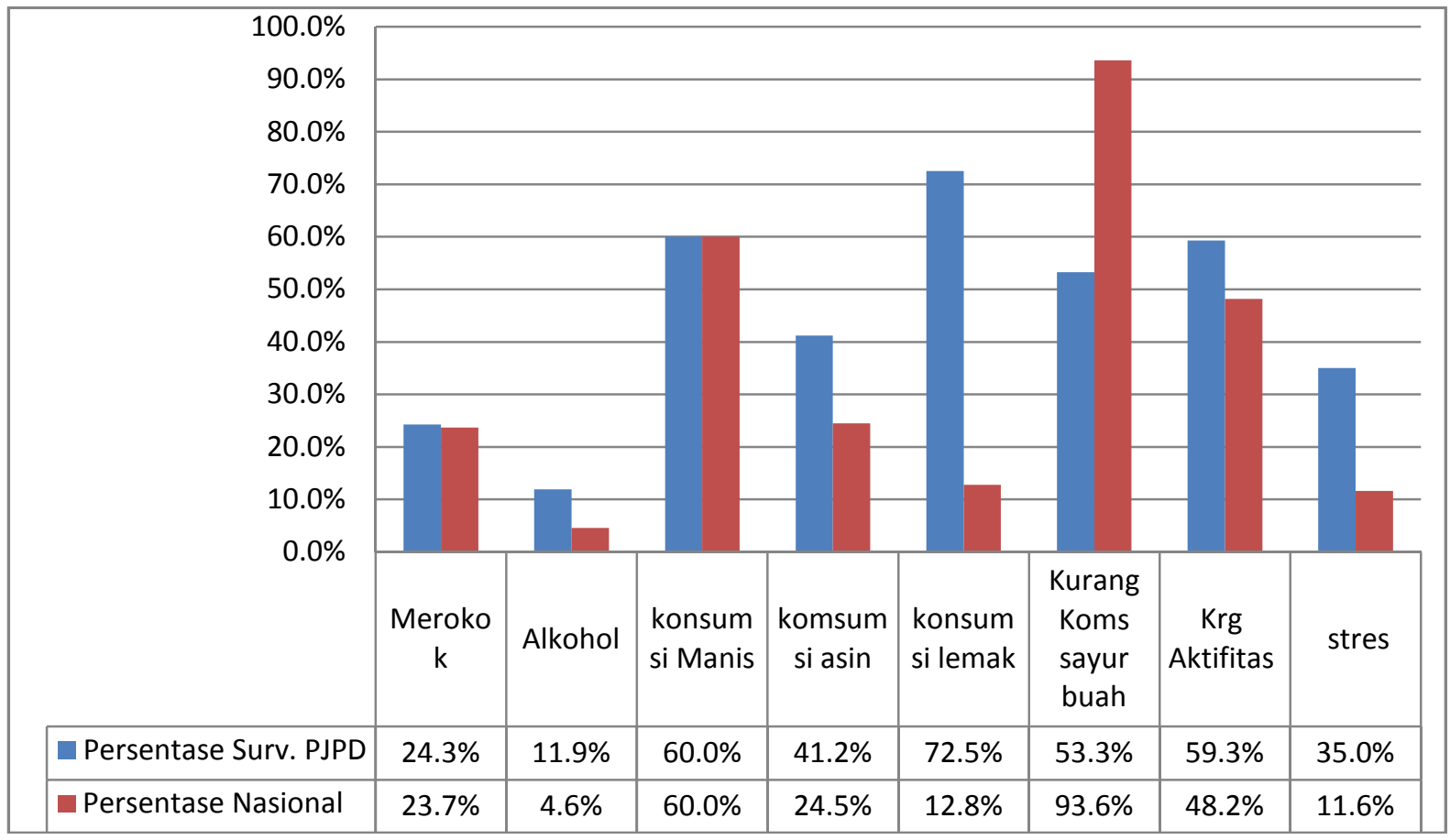

Pada Gambar 2 dapat dilihat bahwa Persentase Hasil Survei Deteksi dini Penyakit Tidak Menular (PJPD) berdasarkan Faktor Risiko Perilaku dan Gaya Hidup untuk faktor kebiasaan merokok, kebiasaan mengkonsumsi alkohol, konsumsi makanan asin, kurang aktifitas dan stress masih diatas persentase nasional, sedangkan untuk faktor kurang komsumsi sayur dan buah berada di bawah persentase nasioanal.

\section{Pembahasan}

Surveilans merupakan komponen esensial yang memiliki core competencies dari sistem P2PL (Pengendalian Penyakit dan Penyehatan Lingkungan) baik pada tingkat nasional maupun tingkat kabupaten dan kota (Achmadi, 2008). Berdasarkan target pencapaian yang telah ditetapkan oleh Dinas Kesehatan Provinsi Riau, dapat diketahui pencapaian program yang telah dilaksanakan yaitu dari 12 kabupaten/kota di Provinsi Riau, 8 kabupaten/kota telah melaksanakan kegiatan deteksi dini faktor risiko PJPD atau sekitar 66,6\%, dengan demikian kegiatan ini telah mencapai target yang telah ditetapkan (30\%).

Surveilans Penyakit Jantung dan Pembuluh Darah terdiri dari surveilans faktor risiko penyakit dan faktor risiko perilaku dan gaya hidup. Dengan surveilans akan diperoleh diperoleh informasi yang essensial yang digunakan untuk pengambilan keputusan dalam upaya pencegahan dan penanggulangan penyakit jantung dan pembuluh darah dengan biaya yang efektif. Jenis penyakit yang dapat digolongkan ke dalam PJPD adalah : (1) Penyakit Jantung Koroner (PJK, penyakit jantung iskemik, serangan jantung, infark miokard, angina pektoris), (2) Penyakit pembuluh darah otak (Stroke, Transiet Ischemic Attack (TIA)), (3) Penyakit Jantung Hipertensi, (4) Penyakit pembuluh darah perifer, (5) Penyakit gagal jantung, (6) Penyakit jantung rematik, (7) Penyakit jantung bawaan, (8) Penyakit 
kardiomiopathy dan (9) Penyakit jantung katub (Depkes, 2007). Faktor risiko PJPD adalah suatu kondisi yang secara potensial berbahaya dan dapat memicu terjadinya penyakit jantung dan pembuluh darah pada orang atau kelompok tertentu (Menkes, 2009).

Berdasarkan hasil deteksi dini, persentase kejadian hipertensi sangat tinggi yaitu mencapai 36,7\%. Angka tersebut jauh diatas prevalensi hipertensi di Provinsi Riau (33,9\%) dan nasional $(31,7 \%)$. Penelitian Meylina (2005) diperoleh bahwa prevalensi hipertensi serta penyakit jantung dan pembuluh darah tertinggi berada di kawasan Sumatera.

Tingginya prevalensi obesitas yang ditemui pada saat survei deteksi dini baik itu obesitas umum $(11,2 \%)$ maupun obesitas sentral $(41,4 \%)$. Obesitas terjadi karena konsumsi makanan yang melebihi kebutuhan Angka Kecukupan Gizi (AKG) perhari. Bila kelebihan ini terjadi dalam jangka waktu lama, dan tidak diimbangi dengan aktivitas yang cukup untuk membakar kelebihan energi, lambat laun kelebihan energi tersebut akan diubah menjadi lemak dan ditimbun didalam sel lemak dibawah kulit (Azwar, 2004). Penelitian Mawi (2003) diperoleh hasil bahwa Indeks Massa Tubuh (IMT) merupakan determinan terjadinya Penyakit Jantung Koroner (PJK), risiko terjadinya PJK pada kelompok overweight lebih besar dibandingkan kelompok ideal dan underweight.

Hasil survei deteksi dini menunjukkan bahwa prevalensi hiperkolesterol $65,4 \%$. Kejadian Diabetes Melitus (DM) ditemui pada saat survei deteksi dini sebesar 5,6\%. Berdasarkan hasil penelitian Framingham dalam Menkes (2009) satu dari dua orang penderita DM akan mengalami kerusakan pembuluh darah dan meningkatkan risiko serangan Jantung. dan kelainan jantung 46,2\%. Penelitian Supriyono (2008) menunjukkan bahwa ada hubungan antara penyakit DM dengan penyakit jantung koroner $(\mathrm{p}=0,026$ dan $\mathrm{OR}=2,4 ; 95 \%$ $\mathrm{CI}=1,2-5,9)$.
Hasil deteksi dini PJPD didapatkan bahwa persentase beberapa prilaku dan gaya hidup tidak sehat dan berisiko PJPD di lokasi survei cukup tinggi. Perilaku dan gaya hidup berisiko ini meliputi kebiasaan merokok (24,3\%), mengkonsumsi alkohol $(11,9 \%)$, konsumsi asin $(41,2 \%)$, kurang konsumsi sayur dan buah $(53,3 \%)$, kurang aktivitas (59,3\%), kebiasaan mengkonsumsi lemak tinggi $(72,5 \%)$ dan stress $(35 \%)$. Dibandingkan dengan persentase nasional, angka tersebut berada di atas persentase nasional.

Berdasarkan data Riskesdas (2007) diperoleh hasil bahwa Persentase nasional Merokok Setiap Hari Pada Penduduk Umur $>10$ Tahun adalah 23,7\%. Sebanyak 17 provinsi mempunyai prevalensi merokok setiap hari pada penduduk umur $>10$ Tahun diatas prevalensi nasional, Salah satunya adalah propinsi Riau.

Data deteksi dini menunjukkan bahwa perilaku konsumsi sayur dan buah berada di bawah persentase nasional dan konsumsi asin (makanan yang tinggi garam) di atas persentase nasional. Artinya bahwa masyarakat kurang mengkonsumsi sayur dan buah dan berlebihan dalam mengkomsumsi makanan yang tinggi garam. Survei juga menunjukkan bahwa kurang aktivitas, kebiasaan mengkonsumsi lemak tinggi dan stress berada di atas prevalensi nasional. Penyakit jantung koroner (PJK) salah satunya disebabkan oleh tingginya tingkat konsumsi asam lemak jenuh. Karena itu, mengurangi risiko PJK bisa dilakukan dengan menggeser pola konsumsi makanan tinggi asam lemak jenuh menjadi pola makan seimbang dengan tinggi serat, olah raga yang teratur dan kurangi stress (Azwar, 2004).

Setelah kegiatan deteksi dini dilakukan, kegiatan selanjutnya adalah melakukan upaya pencegahan dan pengendalian PJPD beserta faktor risikonya khususnya pada masyarakat yang ditemukan mengalami PJPD pada saat deteksi dini. Target upaya pengendalian ini adalah minimal $80 \%$ dari penderita PJPD yang ditemui pada saat deteksi dini terkontrol dan memiliki 
kemandirian serta kesadaran untuk selalu melakukan pemeriksaan kesehatan dalam upaya mengendalikan PJPD yang dialaminya. Dalam upaya pencegahan dan pengendalian PJPD ini sebagai ujung tombak pelaksanaannya adalah Puskesmas dimana kasus PJPD ditemukan.

Untuk pelaksanaan kesinambungan program dalam pengendalian masalah maka alternatif penyelesaian masalah sebagai berikut :

1. Melaksanakan review dan memperkuat "aspek legal" PJPD di unit pelaksana teknis (UPT), dinas kesehatan provinsi, dinas kesehatan kabupaten, dan puskesmas.

2. Melaksanakan advokasi dan sosialisasi program pencegahan pengendalian PJPD dan faktor risikonya.

a. Advokasi dilakukan melalui pendekatan kepada para pimpinan atau penentu/pengambil kebijakan agar memperoleh dukungan dan kemudahan dalam upaya pengendalian PJPD yang dilaksanakan dalam berbagai bentuk kegiatan advokasi baik formal maupun informal.

b. Bentuk kegiatan sosialisasi meliputi penyuluhan (Komunikasi, Informasi, Edukasi/KIE), dukungan/bina suasana, dan pemberdayaan masyarakat.

1) Penyuluhan (KIE)

a) Tersedianya dan terdistribusinya media penyuluhan

b) Terlaksananya penyuluhan tentang pencegahan dan penanggulangan faktor risiko PJPD dengan berbagai metode baik secara perorangan, kelompok, maupun melalui media massa.

2) Bina Suasana

Kelompok sasaran lebih ke tingkat operasional secara berjenjang (tim penggerak PKK, toga, toma, organisasi profesi, NGO, dan lain lain).

3) Pemberdayaan Masyarakat Melaksanakan sosialisasi guna menumbuhkan potensi masyarakat secara optimal dalam pencegahan dan penanggulangan penyakit jantung dan pembuluh darah serta berperan sebagai fasilitator dan regulator kegiatan pengendalian faktor risiko PJPD berbasis masyarakat.

3. Mengembangkan investasi sumber daya manusia antara lain melaksanakan training of trainer (TOT) dan berbagai bentuk pelatihan (training) sesuai dengan kebutuhan dalam pengendalian PJPD.

4. Memfasilitasi terbentuknya dan berperan sebagai regulator jejaring kerja PJPD, kelompok kerja (Pokja), serta jejaring kerja yang sudah ada terkait dengan pengendalian PJPD.

5. Memperkuat logistik peralatan skrining (deteksi dini) faktor risiko PJPD yang bersifat massal di masyarakat dan di fasilitas kesehatan baik ketersediaan (sesuai kebutuhan) maupun manajemennya.

6. Melaksanakan deteksi dini, surveilens epidemiologi, dan pengembangan sistem informasi secara berkala dan berkesinambungan.

7. Melaksanakan supervisi/bimbingan teknis, monitoring, dan evaluasi.

8. Mengembangkan sistem pembiayaan faktor risiko PJPD (melalui APBN, APBD provinsi, APBD kabupaten /kota, sharing cost secara lintas program, lintas sektor, dan sumber daya lainnya).

\section{Kesimpulan}

1. Program Surveilens PTM PJPD di Dinas Kesehatan Provinsi Riau khususnya untuk kegiatan deteksi dini PJPD baru dilaksanakan mulai tahun 2010 yang dilakukan di 8 kabupaten/kota di Provinsi Riau $(66,6 \%$ dari total seluruh 
kabupaten/kota). Pada tahun 2011 akan di laksanakan di seluruh Provinsi Riau.

2. Berdasarkan hasil survei deteksi dini faktor risiko PJPD di Kabupaten Kampar tahun 2011 didapatkan bahwa prevalensi beberapa PJPD dan faktor risikonya di Provinsi Riau khususnya di Kabupaten Kampar cukup tinggi yaitu obesitas umum $11,2 \%$, obesitas sentral 41,4\%, hiperkolesterol 65,4\%, Diabetes Melitus 5,6\%, dan kelainan jantung $46,2 \%$.

3. Hasil survei juga menunjukkan bahwa prevalensi perilaku dan gaya hidup berisiko PJPD juga cukup tinggi yaitu kebiasaan merokok 24,3\%, kebiasaan mengkonsumsi alkohol 11,9\%, kebiasaan mengkonsumsi asin 41,2\%, kebiasaan mengkonsumsi lemak tinggi $72,5 \%$, kurang mengkonsumsi sayur dan buah 53,3\%, kurang aktivitas 59,3\%, dan stress tinggi $35 \%$.

\section{Saran}

1. Perlu dilakukan survei deteksi dini secara berkala dan berkesinambungan untuk mengetahui kecenderungan dan perkembangan PJPD di Provinsi Riau

2. Untuk mendukung kelancaran kegiatan survei deteksi dini tersebut, disamping perlu didukung oleh ketersediaan alat, sarana dan prasarana yang memadai, perlu juga diberikan pelatihan dan bimbingan teknis bagi tenaga kesehatan pelaksana di lapangan khususnya tenaga kesehatan di puskesmas sebagai ujung tombak pelaksana kegiatan deteksi dini PJPD.

3. Perlu dilakukan peningkatan dan intensifikasi kegiatan sosialisasi pengendalian PJPD di masyarakat melalui Komunikasi, Informasi, dan Edukasi (KIE) salah satunya dengan mengintensifkan penyuluhan kesehatan tentang PJPD.

4. Dalam upaya pencegahan dan pengendalian PJPD di masyarakat, hendaknya melibatkan peran serta aktif masyarakat salah satunya dengan memberikan pelatihan bagi kader kesehatan masyarakat tentang upayaupaya pencegahan dan pengendalian PJPD.

\section{Ucapan Terima Kasih}

Ucapan terima kasih ditujukan kepada Kepala Dinas Kesehatan Propinsi Riau, Kepala Bidang P2PL, Kepala Seksi Surveilens dan Kesehatan Matra dan kepada masyarakat Desa Kuapan Kecamatan Tambang kabupaten kampar tempat deteksi dini dilakukan.

\section{Daftar Pustaka}

Achmadi, Umar Fahmi, 2008. Horison Baru Kesehatan Masyarakat di Indonesia, Jakarta : Rhineka Cipta

Anwar, T Bahri (2004) Faktor Risiko Penyakit Jantung Koroner Fakultas Kedokteran USU e-USU Repository [Online] http://repository.usu.ac.id/bitstrea m/.pdf di Akses 7 April 2011

Azwar , Asrul (2004) Tubuh Sehat Ideal Dari Segi Kesehatan Disampaikan pada Seminar Kesehatan Obesitas, Senat Mahasiswa Fakultas Kesehatan Masyarakat UI,Sabtu, 15 Februari, 2004 di Kampus UI Depok. [Online] http:/gizi.net/gaya-hidup/Tubuh-idealsehat.PDF di akses 12 Mei 2011

Depkes RI. (2007). Pedoman pengendalian penyakit jantung dan pembuluh darah. Jakarta

Depkes RI. (2009). Profil kesehatan Indonesia tahun 2008. Jakarta.

Depkes. (2008). Riset Kesehatan Dasar (Riskesdas) 2007. Jakarta.

Dinkes Provinsi Riau. (2010). Profil kesehatan Provinsi Riau tahun 2009. Pekanbaru.

Menkes RI, 2009. Keputusan Menteri Kesehatan Republik Indonesia Nomor 854/Menkes/SK/IX/2009 tentang Pedoman Pengendalian Penyakit Jantung dan Pembuluh Darah. [On line] 
http://www.hukor.depkes.go.id/ Akses 7 Mei 2011

Mawi, Martiem (2003) Indeks massa tubuh sebagai determinan penyakit jantung koroner pada orang dewasa berusia di atas 35 tahun Jurnal Kedokteran Trisakti Vol 23 No 3 p 87-92 [Online] http://www.univmed.org/wpcontent/uploads/2011/02/MARTIM.pdf Akses 7 Mei 2011.

Meylina, Elin (2005) Analisis Faktor Risiko Hipertensi, Diabetes Melitus, Penyakit
Jantung dan Pembuluh Darah di Indonesia, Tesis. Program Gizi Masyarakat dan Sumberdaya Keluarga. Institut Pertanian Bogor [Online] http://repository.ipb.ac.id/ bitstream/ Akses 12 Mei 2011.

Supriyono, Mamat (2008) Faktor-faktor Risiko yang Berpengaruh Terhadap Kejadian Penyakit Jantung Koroner pada Kelompok Usia < 45 tahun, Tesis. [Online] http://eprints.undip.ac.id/18090/1/MAMAT _SUPRIYONO.pdf Akses 12 Mei 2011 